\title{
EFFECT OF PROBIOTIC ORAL ADMINISTRATION ON SKIN WOUND HEALING IN RATS
}

\author{
Efeito da administração oral de probióticos na cicatrização de feridas cutâneas em ratos \\ Eliane TAGLIARI', Leticia Fuganti CAMPOS'1, Antonio Carlos CAMPOS², \\ Thaís Andrade COSTA-CASAGRANDE ${ }^{3}$, Lúcia de NORONHA
}

How to cite this article: Tagliari E, Campos LF, Campos AC, Costa-Casagrande TA, Noronha L. Effect of probiotic oral administration on skin wound healing in rats. ABCD Arq Bras Cir Dig. 2019;32(3):e1457. DOI: /10.1590/0102-672020190001e1457

\begin{abstract}
From the 'Programa de Pós-graduação em Clínica Cirúrgica, Setor de Ciências da Saúde, Universidade Federal do Paraná 2Departamento de Cirurgia, Setor de Ciências da Saúde, Universidade Federal do Paraná; ${ }^{3}$ Mestrado Profissional em Biotecnologia Industrial, Universidade Positivo: ${ }^{4}$ Laboratório de Patologia Experimental, Pontifícia Universidade Católica do Paraná ('Postgraduate Program in Clinical Surgery, Health Sciences Sector, Federal University of Paraná; ${ }^{2}$ Department of Surgery, Health Sciences Sector, Federal University of Paraná; ${ }^{3}$ Professional Master Program in Industrial Biotechnology, Positivo University, ${ }^{4}$ Pathology Laboratory, Pontifical Catholic University of Paraná), Curitiba, PR, Brazil
\end{abstract}

HEADINGS - Probiotics. Wound healing. Rats. Administration, oral.
ABSTRACT - Background: Manipulating intestinal microbiota with probiotics might stimulate skin response. Understanding all stages of the healing process, as well as the gut-skin-healing response can improve the skin healing process. Aim: To evaluate the effect of perioperative oral administration of probiotics on the healing of skin wounds in rats. Methods: Seventy-two Wistar male adult rats were weighed and divided into two groups with 36 each, one control group (supplemented with oral maltodextrin $250 \mathrm{mg} /$ day) and one probiotic group (supplemented with Lactobacillus paracasei LPC-37, Bifidobacterium lactis HN0019, Lactobacillus rhamnosus HN001, Lactobacillus acidophilus NCFM ${ }^{\circledast}$ at a dose of $250 \mathrm{mg} /$ day), both given orally daily for 15 days. The two groups were subsequently divided into three subgroups according to the moment of euthanasia: in the $3^{\text {rd }}, 7^{\text {th }}$ and $10^{\text {th }}$ postoperative days. Results: There were no significant changes in weight in both groups. Wound contraction was faster in probiotic group when compared to the controls, resulting in smaller wound area in the $7^{\text {th }}$ postoperative day. As for histological aspects, the overall H\&E score was lower in the probiotic group. The probiotic group showed increased fibrosis from $3^{\text {rd }}$ to the $7^{\text {th }}$ postoperative day. The type I collagen production was higher in the probiotic group at the $10^{\text {th }}$ postoperative day, and the type III collagen increased in the $7^{\text {th }}$. Conclusion: The perioperative use of orally administrated probiotic was associated with a faster reduction of the wound area in rats probably by reducing the inflammatory phase, accelerating the fibrosis process and the deposition of collagen.

\section{Correspondência:}

Eliane Tagliari

E-mail: elianetagliari@yahoo.com.br

Financial source: This study was financed in part by FQM-FARMA, and in part by Coordenação de Aperfeiçoamento de Pessoal de Nível Superior, Brazil (CAPES) Finance Code 001

Conflict of interest: none

Received for publication: 10/06/2019 Accepted for publication: 22/07/2019

DESCRITORES - Cicatrização. Administração oral. Probióticos. Ratos.
RESUMO - Racional: Manipular a microbiota intestinal parece auxiliar na resposta cutânea. Entender todas as etapas do processo de cicatrização, bem como a resposta intestino-pelecicatrização, pode ser ferramenta complementar no reparo cutâneo. Objetivo: Avaliar o efeito de suplementação perioperatória de probióticos via oral na cicatrização de feridas cutâneas excisionais em ratos. Métodos: Setenta e dois ratos adultos, machos Wistar, foram divididos em dois grupos de 36, sendo um de controle (suplementado com maltodextrina $250 \mathrm{mg} / \mathrm{dia}$ ) e outro probiótico (suplementado com Lactobacillus paracasei LPC-37, Bifidobacterium lactis HN0019, Lactobacillus Rhamnosus HN001, Lactobacillus Acidophilus NCFM ${ }^{\star}, 250$ mg/dia). Resultados: Não houve modificação significativa de peso em ambos os grupos. A contração da ferida foi mais rápida no grupo probiótico, quando comparada ao controle, resultando em menor área cruenta no sétimo dia do pós-operatório. Quanto aos aspectos histológicos, o escore geral do HE foi menor no grupo probiótico. O grupo probiótico apresentou maior fibrose do terceiro ao sétimo dias pós-operatórios. A produção de colágeno tipo I foi maior no grupo probiótico no décimo dia pós-operatório, e do tipo III maior no sétimo. Conclusão: O uso perioperatório do probiótico via oral foi associado à redução mais rápida da área cruenta da ferida cutânea em ratos, possivelmente por reduzir a fase inflamatória, acelerando a fibrose e o processo de deposição de colágeno.

\section{INTRODUCTION}

$\mathrm{T}$ he skin is a varied ecosystem composed of $1.8 \mathrm{~m}^{2}$ of tissue that covers the whole body, rich in folds, cutaneous attachments and contains a diverse microbiota ${ }^{11}$. Recently, advanced molecular analyses of the cutaneous microbiota revealed a great diversity and these vary according to its topographic location on the body ${ }^{7}$. Healing is a dynamic cellular process involving molecular and biochemical events aimed at tissue reconstitution ${ }^{3,4}$. Healing can be evaluated by clinical, mechanical, biochemical and histological parameters ${ }^{3,4}$. The microbiota of the skin also plays a key role in the immunological response and can interfere in the wound healing ${ }^{20}$. The perception of the skin as an ecosystem rich in living biological components and present in different locations explains the delicate balance between host and microorganisms. The skin microbiota is influenced by the intestinal 
microbiota and has also been shown to interact with the host symbiotically, modulating inflammation and the immune system, acting on the biotransformation of xenobiotics and the absorption of micronutrients, synthesizing vitamins, enzymes and proteins used by the host, fermenting energy substrates, providing resistance to pathogens and changing the amount of energy available in the $\operatorname{diet}^{26}$. The manipulation of the healing process with the use of probiotics has been studied both by topical application as well as by oral use. Probiotics are defined by the World Health Organization as "live microorganisms that when given in adequate amounts, confer a health benefit to the host ${ }^{8,24,26,29}$. Probiotics have been associated with improved healing of intestinal ulcers and healing of cutaneous wounds, among other actions already described in the literature ${ }^{20}$.

The objective of this study was to analyze the effect of the oral administration of probiotics on cutaneous healing in rats by macroscopic and histological aspects as well as by the deposition of collagen on the wound.

\section{METHODS}

The study was part of the research on Tissue Healing of the Graduate Program in Surgery of the Federal University of Parana, Curitiba, Brazil. The animal experiments were carried out in accordance with the norms established by the Brazilian Federal Law No. 11,794, of October 8, 2008, Resolution 196/96 of the National Health Council, norms foreseen by the National Council of Control of Animal Experimentation (CONCEA) after approval of the Ethics Committee on the Use of Animals (CEUA) of the Positivo University (Opinion No. 294).

\section{Animals and probiotic administration}

During the whole experiment the animals were packed in appropriate polypropylene boxes with wooden chips bed, receiving water and fed with Presence ${ }^{\circledR}$-Purina ad libitum. Two animals were housed per box, kept in an air conditioned room at a constant temperature of $21^{\circ} \mathrm{C}$, with humidity control and exposed to the brightness of $12 \mathrm{~h}$ of light a day, automatically controlled. A total of 72 adult male Wistar rats weighing \pm 250 $\mathrm{g}$ obtained from the Positivo University laboratory were used. The rats were weighed and divided into two groups with 36 animals each, one control which received maltodextrin $250 \mathrm{mg} /$ day) and one probiotic group supplemented with a probiotic Probiatop ${ }^{\circledR}$ from FQM-FARMA compound that contained Lactobacillus paracasei LPC-37, Bifidobacterium lactis HN0019, Lactobacillus rhamnosus HN001, Lactobacillus acidophilus $\mathrm{NCFM}^{\circledR}$, at the dose of $250 \mathrm{mg} /$ day, which corresponds to the approximate dose of 200,000 to 210,000 CFU (colony forming units), administered orally once a day, starting five days before surgery until the euthanasia day, with the aid of a spatula ${ }^{24}$ mixed in cream cheese. The two groups were subsequently divided into three subgroups according to the moment of the euthanasia in the $3^{\text {rd }}$ postoperative (3PO) day; $7^{\text {th }}$ postoperative (7PO) day and $10^{\text {th }}$ postoperative (10PO) day, with 12 rats each.

\section{Surgical procedure}

After five days of preoperative oral administration of either probiotics or maltodextrin, the rats were anesthetized and subjected to an excisional dorsal square wound, standardized by a mold measuring $2 \times 2 \mathrm{~cm}$. The anesthesia was via inhalation (isoflurane) and then maintained with an association of ketamine hydrochloride $80 \mathrm{mg} / \mathrm{kg}$ and hydrochloride of xylazine $10 \mathrm{mg} / \mathrm{kg}$ intramuscularly, being maintained under the inhalation effect of the anesthetic throughout the procedure. After recovery, they returned to their original cages receiving water and were allowed rat chow ad libitum. Liquid acetaminophen was used in a daily dose of $200 \mathrm{mg} / \mathrm{kg} /$ day orally, until the $4^{\text {th }}$ postoperative day. They were evaluated in 3PO; $7 \mathrm{PO}$ and $10 \mathrm{PO}$ days (Figure 1).

\begin{tabular}{|c|c|c|c|c|}
\hline $\begin{array}{c}\text { Start of } \\
\text { probiotic or } \\
\text { maltodextrin } \\
\text { administration }\end{array}$ & $\begin{array}{c}\text { Surgical } \\
\text { procedure, } \\
\text { photo and } \\
\text { weighing }\end{array}$ & $\begin{array}{c}\text { Photo and } \\
\text { weighing }\end{array}$ & $\begin{array}{c}\text { Photo and } \\
\text { weighing }\end{array}$ & $\begin{array}{c}\text { Photo and } \\
\text { weighing }\end{array}$ \\
\hline Day -5 & Day 0 & 3rd PO Day & 7th PO Day & $\begin{array}{c}\text { 10th PO } \\
\text { Day }\end{array}$ \\
\hline & $\begin{array}{c}\text { Euthanasia } \\
\text { and excision } \\
\text { of lesion of } \\
\text { subgroups } \\
\mathrm{C}_{3} \text { and } \mathrm{P}_{3}\end{array}$ & $\begin{array}{c}\text { Euthanasia } \\
\text { and excision } \\
\text { of lesion of } \\
\text { subgroups } \\
\mathrm{C}_{7} \text { and } \mathrm{P}_{7}\end{array}$ & $\begin{array}{c}\text { Euthanasia } \\
\text { and lesion of } \\
\text { subgroups } \\
\mathrm{C}_{10} \text { and } \mathrm{P}_{10}\end{array}$ \\
\hline
\end{tabular}

FIGURE 1 - Study design

The wounds were photographed at a standard distance of $15 \mathrm{~cm}$. The analysis and calculation of the areas, in square millimeters, were performed by the Image-Pro ${ }^{\oplus}$ Plus software (version 4.5, Media Cybernetics, Rockville, Maryland, USA).

\section{Euthanasia and collection of materials}

On the $3 \mathrm{PO}\left(\mathrm{C}_{3}\right.$ and $\left.\mathrm{P}_{3}\right), 7 \mathrm{PO}\left(\mathrm{C}_{7}\right.$ and $\left.\mathrm{P}_{7}\right)$ and $10 \mathrm{PO}\left(\mathrm{C}_{10}\right.$ and $\left.P_{10}\right)$ days the rats were also submitted to euthanasia in a closed system with isoflurane. Immediately after death, the lesions were excised and the entire wound extension with a $1 \mathrm{~cm}$ margin of intact skin were included and stored with $10 \%$ formaldehyde in order to preserve their morphological structures for later histological study and collagen densitometry determination.

\section{Histological analysis}

The pieces were cut into blocks in a rotating microtome, with cuts of five micrometers thickness. For each wound, a histological slide was made with 3-6 cuts. The sections were executed perpendicular to the surface of the dermis, in the central region and at the edges of the wound and submitted to dehydration and diaphanization in xylol and stained with $\mathrm{H} \& \mathrm{E}$. The reading of the slides was performed under an Olympus BX40 optical microscope (Tokyo, Japan), with magnifications of 20x. The types and quantity of the predominant cells in the inflammatory reaction (neutrophils), the presence of interstitial edema and vascular congestion, and the degree of fibroblast, neovascularization and macrophage tissue formation were evaluated. The data were classified as accentuated (3), moderate (2) and discrete (1), according to the intensity in which they were found, and transformed into quantitative variables by assigning index to the histological findings. The presence of edema, congestion and polymorphonuclear cells were indicative of an acute inflammatory process, punctuating negatively, and the formation of fibroblasts, neovascularization and monocytes were findings that indicated a chronic inflammatory process, punctuating positively. After the assignment of the indices, these were added to a total final score for subsequent statistical comparison between the groups ${ }^{25}$.

\section{Collagen densitometry}

Histological slides were stained with Picrosirius-red F3BA and photographed, were each image was captured under normal light and polarized light. Four fields per wound were selected for the slide readings, in a standardized way, two of the border and two of the central area of the wound, always from top to bottom. Images were transmitted from the ScopeA $1^{\oplus}$ microscope (Zeiss, Germany) connected to the AxioCam MRc (Zeiss, Germany) digital camera to an HP ZR2440W color monitor. The images were recorded by AxioVision 4.9 Software and were analyzed by the Image-Pro Plus ${ }^{\circledR} 4.5$ software (Media Cybernetics, Rockville, Maryland, United States). In the RGB (Red, Green, Blue) system, the thicker and more strongly birefringent collagen fibers are colored with red-orange (type I or mature collagen), and the thinner, sparsely birefringent fibers were colored with shades of green (type III or immature collagen). 


\section{Statistical analysis}

The results were described by averages, medians, minimum values, maximum values and standard deviations. For the comparison between the groups, on each day of evaluation, the non-parametric Mann-Whitney test was used. The comparisons between the evaluation days, within the control and probiotic groups, were made using the Kruskal-Wallis non-parametric test. Values of $p<0.05$ indicated statistical significance. The data was organized in an Excel spreadsheet and analyzed with the IBM SPSS Statistics ${ }^{\circledR}$ software, v.20.

\section{RESULTS}

Throughout the experiment, there were no deaths. The body weight did not present significant changes in any group during the whole experiment (day -5 (3PO $p=0.150 ; 7 \mathrm{PO}$ $p=0.410 ; 10 P O p=0.107)$, day $0(3 P O p=0.867,7 P O p=0.0851$, $10 \mathrm{PO} \mathrm{p}=0.185)$, day $3 \mathrm{PO}(3 \mathrm{PO} \mathrm{p}=0.741 ; 7 \mathrm{PO}=0.599 ; 10 \mathrm{PO}$ $p=0.629)$, day 7PO (7PO $p=0.730 ; 10 P O p=0.549)$ and $10 P O$ (10PO $\mathrm{p}=0.937)$.

\section{Histological analysis}

In Figure 2A are shown the results for the histological indicators of the inflammatory reaction. For the edema, congestion and polymorphonuclear variables, there was no significant difference at any moment when the control and probiotic groups were compared. Fibrosis at the 7PO day was significantly higher in the probiotic group when compared to controls $(p=0.028)$. For the neovascularization and monocyte variables, there were no significant differences between the groups. Also in Figure 2B it can be seen that the overall $H \& E$ score was better in the probiotic group when compared to the control in the 3PO $(p=0.017)$ and $7 P O(p=0.014)$. Figure 3 shows examples of the histological evolution (edema, congestion, polymorphonuclear, fibrosis, neovascularization and monocytes) between control and probiotic, at the 3PO, 7PO and 10PO days. It was observed that the probiotic group showed less edema, congestion and polymorphonuclears and the counting of the monocytes was equivalent.

\section{Collagen analysis}

Table 1 shows the results of the evaluation of the wound deposition of Type I and Type III collagens. The type I was higher in the probiotic group on the 10PO $(p=0.007)$ as compared to the control group. There was an increase in type III collagen in the 7PO $(p=0.014)$ in the probiotic group when compared to the control group. In Figure 4 the distribution of type I and type III collagens is shown at times 3PO, 7PO and 10PO, for both the control and the probiotic groups.

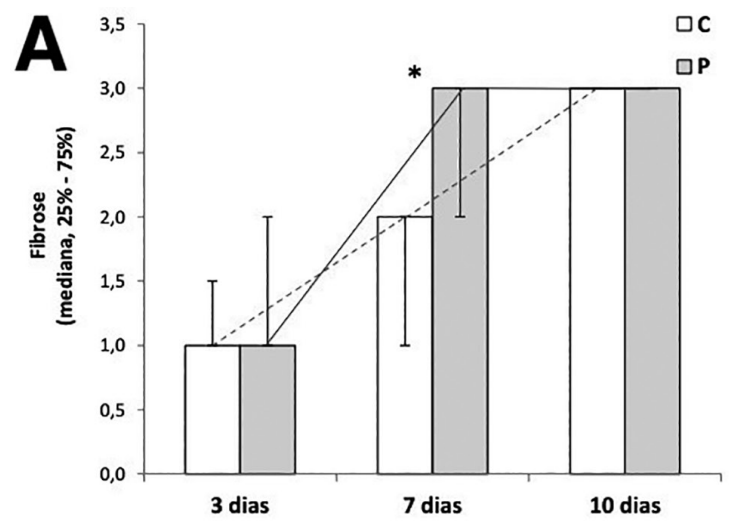

Grupo Controle (C) e Probiótico (P); ( mediana 25\%-75\%), nos tempos $0 \mathrm{PO} ; 3 \mathrm{PO} ; 7 \mathrm{PO} ; 10 \mathrm{PO} * \mathrm{P}=0.028$.
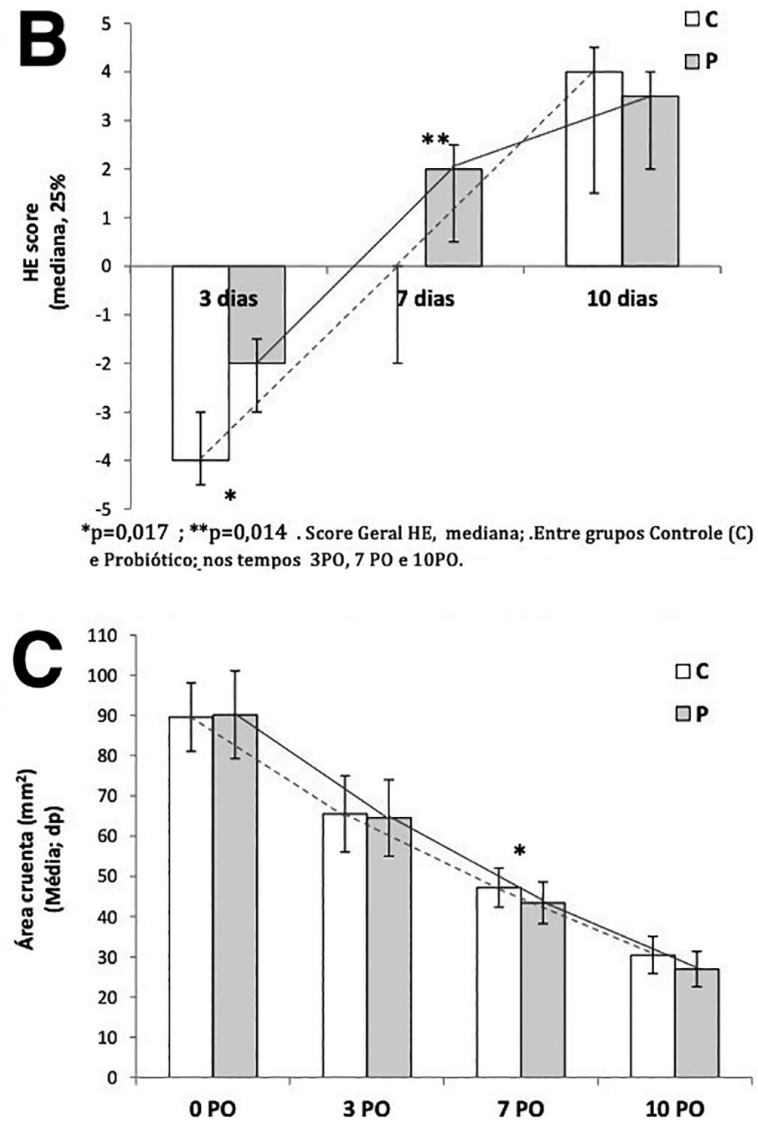

$\mathrm{p}=0,013$. Grupo Controle (C) e Probiótico (P); média e desvio padrão (dp). nos tempos 0P0;3P0;7P0;10PO

Expressed in mean+standard deviation

FIGURE 2 - At times 3PO, 7PO and 10PO between Control $(C)$ and Probiotic (P) groups: $A$ ) graph showing the amount of fibrosis; B) graph showing cell histological evolution; $C$ ) graph showing the wound tissue area $\left(\mathrm{mm}^{2}\right)$, at times $3 \mathrm{PO}, 7 \mathrm{PO}$ and $10 \mathrm{PO}$.

TABLE 1 - Evaluation of collagen I and collagen III (in the total area), expressed in $\mathrm{mm}^{2}$, in the control and probiotic groups, at times 3PO, 7PO and 10PO

\begin{tabular}{|c|c|c|c|c|c|c|}
\hline \multirow{2}{*}{ Variable } & \multirow{2}{*}{ Group } & \multirow{2}{*}{$\mathrm{n}$} & \multicolumn{3}{|c|}{ Mean \pm standard deviation } & \multirow{2}{*}{$\mathrm{p}^{*}\left(3^{\text {rd }} \times 7^{\text {th }} \times 10^{\text {th }}\right)$} \\
\hline & & & 3PO day & 7PO day & $10 P O$ day & \\
\hline \multicolumn{7}{|l|}{ Collagen I } \\
\hline \multirow[t]{3}{*}{ Area $\left(\mathrm{mm}^{2}\right)$} & Control & 12 & $1.33 \pm 0.88$ & $0.96 \pm 0.85$ & $0.62 \pm 0.61$ & 0.313 \\
\hline & Probiotic & 12 & $1.75 \pm 0.66$ & $0.30 \pm 0.23$ & $1.38 \pm 0.73$ & $<0.001$ \\
\hline & $\mathrm{p}^{\star *}(\mathrm{C} \times \mathrm{P})$ & & 0.266 & 0.028 & 0.007 & \\
\hline \multicolumn{7}{|l|}{ Collagen III } \\
\hline \multirow[t]{3}{*}{ Area $\left(\mathrm{mm}^{2}\right)$} & Control & 12 & $0.019 \pm 0.014$ & $0.018 \pm 0.010$ & $0.032 \pm 0.027$ & 0.598 \\
\hline & Probiotic & 12 & $0.014 \pm 0.013$ & $0.029 \pm 0.012$ & $0.029 \pm 0.028$ & 0.023 \\
\hline & $\mathrm{p}^{\star \star}(\mathrm{C} \times \mathrm{P})$ & & 0.178 & 0.014 & 0.932 & \\
\hline
\end{tabular}




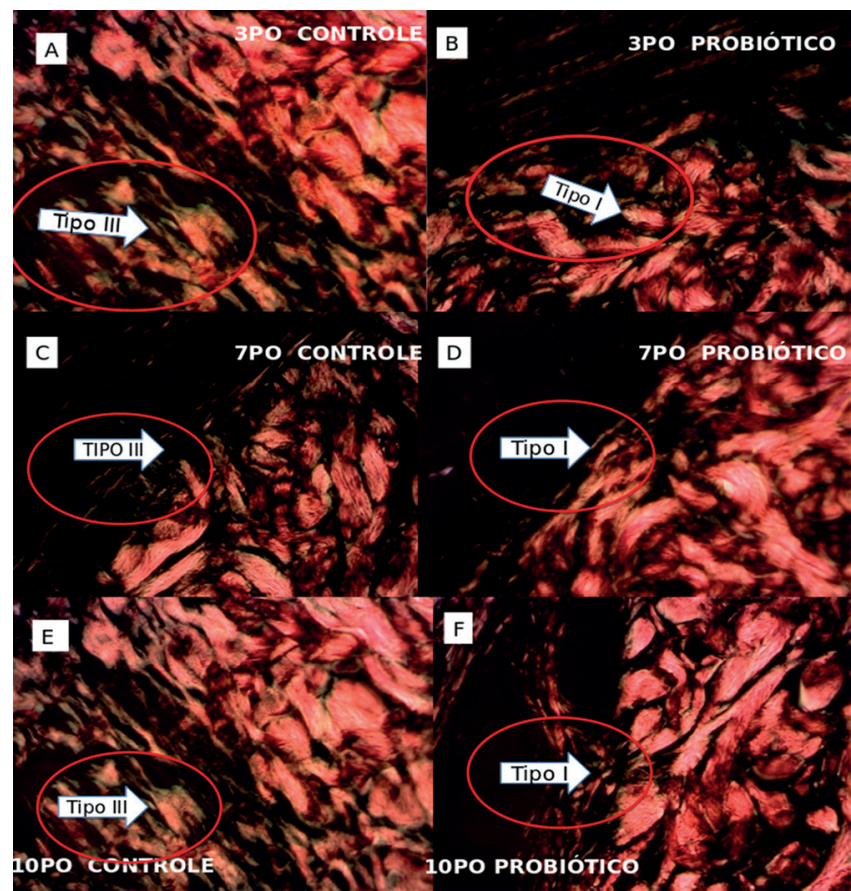

Collagen type I (stained in red) and collagen type III (stained in green); Picrosirius red F3BA (PSR), 20x

FIGURE 3 - Histological evolution (edema, congestion, polymorphonuclear, fibrosis, neovascularization and monocytes) between control and probiotic: $\mathrm{A}$ and $\mathrm{B}$ ) 3PO $\mathrm{A}=$ control, $\mathrm{B}=$ probiotic; $\mathrm{C}$ and $\mathrm{D}$ ) $7 \mathrm{PO} C=$ control; $\mathrm{D}=$ probiotic); $\mathrm{E}$ and $\mathrm{F}$ ) $10 \mathrm{PO}$ $\mathrm{E}=$ control and $\mathrm{F}=$ probiotic
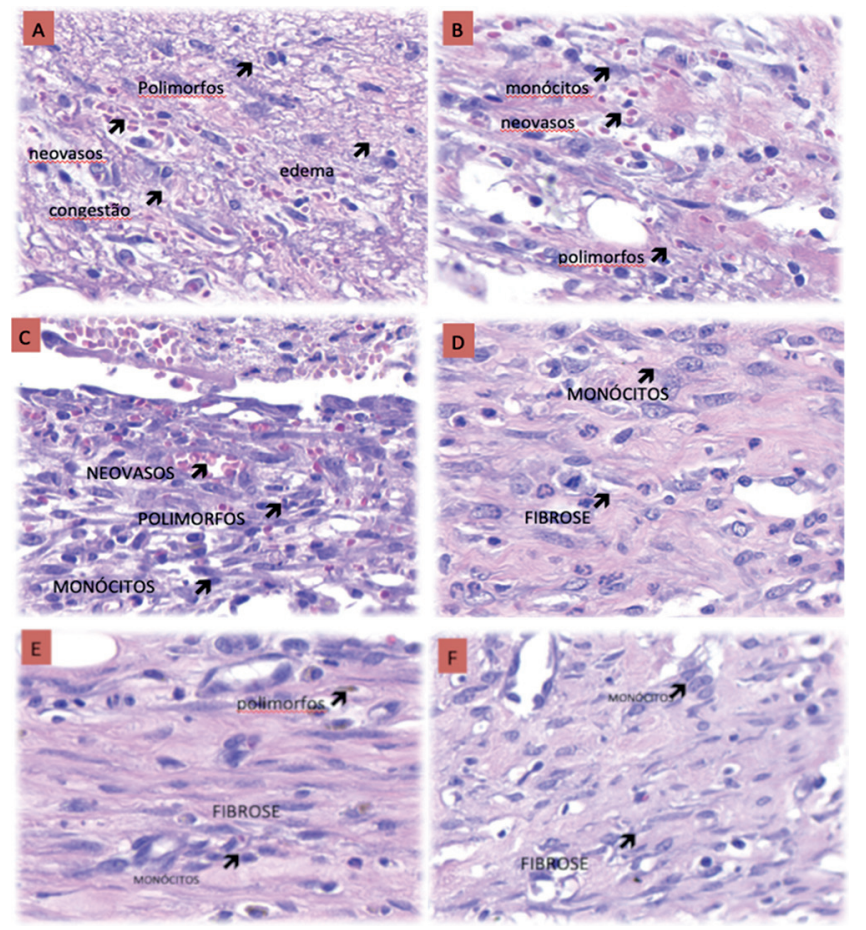

FIGURE 4 - Example of histological evolution (edema, congestion, polymorphonuclears, fibrosis, neovascularization and monocytes) in both control and probiotic groups at the 3PO (A and $\mathrm{B}), 7 \mathrm{PO}(\mathrm{C}$ and $\mathrm{D})$ and $10 \mathrm{PO}(\mathrm{E}$ and $F$ ) days

\section{Wound tissue area}

As described in Figure 2C, wound contraction was higher in the probiotic group in the 7PO when compared to the control, resulting in a smaller wound tissue area (43.4 \pm 5.2 vs.
$47.2 \pm 4,9 \mathrm{~mm}^{2}, \mathrm{p}=0.013$ ). As shown in Figure 4, the evolution of wound contraction was faster in the probiotic group as compared to controls.

\section{DISCUSSION}

Probiotics and their metabolites are considered regulators of various biological functions, and their effects are being studied in the intestine-skin axis, controlling the healing of wounds ${ }^{7}$. Probiotics can be used topically or systemically (by the oral route). Many studies relate the benefits of applying probiotics topically, demonstrating improvement in wound healing by reducing bacterial load and increasing tissue repair in rodent wound models ${ }^{16}$. The systemic effects of probiotics promote the connection between the intestinal and the cutaneous microbiota, decrease inflammation, alter the composition of the microbiota in both sites and regulate the innate immune system ${ }^{28}$. The oral use improves the intestinal microbiota and the absorption of essential nutrients for the wound healing, such as vitamins, minerals and cofactors for the key enzymes involved in the regulation of cutaneous healing ${ }^{16,28}$.

Scotti et al. ${ }^{23}$ showed in their review that differences in the microbial composition of the intestine can affect the homeostasis of energy extraction, which may imply in gain or loss of weight in the host when supplemented with probiotic. In this study, there was no difference in weight on the days evaluated in any groups.

Wound healing is a highly dynamic process involving a complex sequence of cellular and biochemical events, ranging from an immediate response to skin cell damage and invasive microbial signals to inflammatory, angiogenic, and ultimately fibroplasia and scar formation $3,4,21,28$. The phenomena occur simultaneously, self-regulated and interfering with each other. It has been divided into three dynamic phases: inflammatory phase, proliferative phase and remodeling phase $e^{4,5,29}$. The interaction between inflammation, cell and humoral responses with intense cytokines production and liberation is fundamental for the healing process itself ${ }^{21}$. The present study describes a model of cutaneous excisional wound healing in rats in order to evaluate the effect of the oral administration of probiotic on skin wound healing. Macroscopic and microscopic evaluations of cutaneous wounds in rats were done in three different moments: the 3PO, 7PO, and 10PO days.

Neutrophils are the first cells recruited to the lesion area. Their main function is to protect the host from infection by combating invasive microorganisms and/or by removing cellular debris, as well as presenting antigens. However, activated neutrophils secrete bioactive substances, such as proteases and free radicals, which can lead to tissue damage if in excess $5^{5,28}$. The keratinocytes then migrate into the injured dermis and proliferate to form the granulation tissue which is intended to restore skin barrier function. Fibroblasts invade the clot and angiogenesis occurs, followed by tissue remodeling, controlled by fibroblasts that produce collagen and form the scar ${ }^{5,17}$.

Many monocyte and macrophage functions have been linked to the activation of Toll-like receptors (TLRs) ${ }^{12,13,15,18}$. The response to skin lesions in animals is triggered by molecular patterns associated with host-derived damage and the activation of inflammatory cells ${ }^{13}$. The findings of acute inflammatory process, such as interstitial edema and vascular congestion, are less closely linked to the process of cell proliferation, whereas the chronic inflammatory process is histologically related to the polymorphonuclear infiltrate, granulation tissue and fibrosis ${ }^{25}$. Fibrosis is defined as the interstitial fiber deposit that marks the onset of the scar ${ }^{25}$.

The proliferative phase, marked by the presence of fibrosis, was faster in the probiotic group on the 7PO day, when compared to the controls, resulting in a smaller wound tissue area at that moment. Probably the use of probiotic stimulated 
the collagen deposition and facilitated the fibrosis, improving the healing process. The amount of collagen on the 7PO day in the probiotic group was equivalent to that observed in controls on the 10PO day. When analyzing the H\&E general score, it is expected that in the initial phase (3PO) the scores are negative, but in the probiotic group these were less negative. At 7 days (7PO), when the subacute phase starts, the probiotic group score was already positive, showing a faster resolution of the healing process in the probiotic group when compared to the control group. In the 10PO the probiotic group showed signs of stabilization of the chronic healing phase and signs of matrix remodeling.

The reduction of the wound area was faster in the probiotic group. By comparing wound area contraction, fibroblast proliferation and histological evolution it is clear that the group supplemented with probiotic had a better resolution of the healing process.

A possibly involved mechanism in this process is related

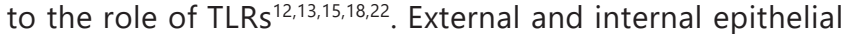
coating tissues express TLRs, such as the skin and the gut. The commensal microbiota expresses antimicrobial peptides (AMPs) ${ }^{13,15}$. AMPs also stimulate and increase TLR pathways. They induce the production of chemokines with chemotactic activity and also modulate the function of dendritic cells and T-lymphocytes to promote wound healing and to maintain skin barrier homeostasis ${ }^{12,13,15,18}$. The expression of TLR in neutrophils, fibroblasts, monocytes and macrophages is essential for the healing response ${ }^{18,22}$. The appearance of TLR ligands indicates change in tissue integrity, which requires containment and repair. TLR-deficient animals were delayed in wound healing especially in the neovascularization, re-epilation and fibrosis processes ${ }^{18}$. The role of TLRs in cutaneous healing has been heavily explored in scientific studies, especially in relation to scar fibrosis $12,13,15,18,19,22$. According to the results found in the histological markers, it is believed that these were probably related to the action of probiotics, via TLRs, on the cutaneous healing in rats.

The findings were also confirmed by the collagen deposition analysis. Type III collagen is rich in water, poorly polymerized and works as a filler. Type I is low in water, very polarized and its function is traction. The resistance of a scar is given by the amount of collagen deposited and by the way the fibers are deposited ${ }^{10,22}$. The healing process begins from the periphery to the center, boosting the organization of the fibers to remodel the collagen. The filling given by type III collagen to the scar area was greater and occurred on the 7PO in the probiotic group, but not in the control group, resulting in a greater production of collagen type I, which was greater in the probiotic group at the $10 \mathrm{PO}$ day. Poutahidis et al. ${ }^{19}$ evaluated the oral use of probiotic drink (L. reuteri) in mice, and the wound closure was marked by accelerated maturation of the granulation tissue and collagen deposition, what occurred from the sixth postoperative day in the group supplemented with $L$. reueri when compared to the controls supplemented with water, similar to our findings.

Modulating the microbiota using probiotics of different species involves a variety of possible mechanisms, including: a) competition with pathogenic bacteria by nutrients and binding sites in the host cell; $b$ ) inactivation of toxins and metabolites; $c$ ) production of antimicrobial substances that inhibit the growth of pathological microorganisms; d) stimulation/modulation of the host immune response, involving epithelial cells, dendritic cells and regulatory $\mathrm{T}$ - lymphocytes, both in the gastrointestinal tract and in the skin ${ }^{6,19}$

Advanced studies done in animal models and also in humans showed the beneficial effects between gut bacteria and a healthier appearance of the skin. One of them, carried out by Levkovich et al. ${ }^{24}$, brought positive results with Lactobacillus reuteri supplementation in increasing dermal thickness and folliculogenesis, as well as potentiating sebum production and improving skin brightness ${ }^{25}$
Heydari et al. ${ }^{9}$ studied the effect of probiotic (L. plantarum) on cutaneous wounds of rats, on days 1, 3, 7, 14 and 21PO, where the results showed an earlier acute phase, with a lower total number of neutrophils in the 3PO and reduction of the wound area, probably by reducing inflammation and the released growth factors, which may have helped to achieve an earlier re-epithelization. These findings corroborate the results presented here.

Probiotics also participate in the improvement of skin differentiation and keratinization process, in the modulation of the cutaneous immune response and in the process of cutaneous healing ${ }^{19}$. Probiotics given orally result in increased Treg Foxp3 + cells in the lymph nodes of the skin, positively regulating the expression of IL10, decreasing tissue damage at the border of the wound and reducing inflammation in the murine model ${ }^{1}$.

\section{CONCLUSION}

The perioperative use of orally administrated probiotic was associated with a faster reduction of the wound area in rats probably by reducing the inflammatory phase, accelerating the fibrosis process and the deposition of collagen.

ORCIDO

Eliane Tagliari - 0000-0002-0263-6147

Antonio Carlos Ligocki Campos - 0000-0001-5080-8380

Lucia de Noronha - 0000-0003-0310-7164

\section{REFERENCES}

1. Belkaid $Y$, Tamoutounour S. The influence of skin microorganisms on cutaneous immunity. Nature Reviews Immunology.2016;16(6):353-366.

2. Borkowski A, Gallo R. UVB Radiation Illuminates the Role of TLR3 in the Epidermis.Journal of Investigative Dermatology.2014;134(9):2315-2320.

3. Campos A, Borges-Branco A, Groth A. Cicatrização de feridas. $A B C D$ Arquivos Brasileiros de Cirurgia Digestiva (São Paulo). 2007:20(1):51-58.

4. Campos A, Groth A, Branco A. Assessment and nutritional aspects of wound healing. Current Opinion in Clinical Nutrition and Metabolic Care. 2008;11(3):281-288.

5. CastilhoT, CamposA, MelloE. Effect ofOmega-3 Fatty Acid in the Healing Process of Colonic Anastomosis in Rats. ABCD Arquivos Brasileiros de Cirurgia Digestiva (São Paulo). 2015;28(4):258-261.

6. Chen L, Guo S, Ranzer M, DiPietro L. Toll-Like Receptor 4 Has an Essential Role in Early Skin Wound Healing. Journal of Investigative Dermatology. 2013;133(1):258-267.

7. Dethlefsen L, McFall-Ngai M, Relman D. An ecological and evolutionary perspective on human-microbe mutualism and disease. Nature. 2007;449(7164):811-818.

8. Flesch A, PoziomyckA, Damin D. Thetherapeuticuse of symbiotics. ABCD Arquivos Brasileiros deCirurgiaDigestiva(SãoPaulo).2014;27(3):206-209.

9. Heydari Nasrabadi. Study of cutaneous wound healing in rats treated with Lactobacillus plantarum on days 1, 3, 7, 14 and 21. African Journal of Pharmacy and Pharmacology. 2011;5(21)

10. Houdek M, Wyles C, Stalboerger P, Terzic A, Behfar A, Moran S. Collagen and Fractionated Platelet-Rich PlasmaScaffold forDermal Regeneration. Plastic and Reconstructive Surgery. 2016;137(5):1498-1506

11. Komatsu N, Saijoh K, Sidiropoulos M, Tsai B, Levesque M, Elliott M et al. Quantification of Human Tissue Kallikreins in the Stratum Corneum: Dependence on Age and Gender. Journal of Investigative Dermatology. 2005;125(6):1182-1189.

12. LaiY, DiNardoA, Nakatsuji T, LeichtleA, YangY, CogenAetal.Commensal bacteria regulate Toll-like receptor 3-dependent inflammation after skin injury. Nature Medicine. 2009;15(12):1377-1382.

13. Lai Y, Gallo R. Toll-Like Receptors in Skin Infections and Inflammatory Diseases. Infectious Disorders - Drug Targets. 2008;8(3):144-155.

14. Levkovich $T$, Poutahidis $T$, Smillie $C$, Varian $B$, Ibrahim $Y$, Lakritz J et al. Probiotic Bacteria Inducea'Glow of Health'. PLoSONE. 2013;8(1):e53867.

15. Lin Q, Wang L, Lin Y, Liu X, Ren X, Wen S et al. Toll-Like Receptor 3 Ligand Polyinosinic:Polycytidylic Acid Promotes Wound Healing in Human and MurineSkin.JournalofInvestigative Dermatology.2012;132(8):2085-2092.

16. Lukic J, Chen V, Strahinic I, Begovic J, Lev-Tov H, Davis S et al. Probiotics or pro-healers: the role of beneficial bacteria in tissue repair. Wound Repair and Regeneration. 2017;25(6):912-922 
17. Nery R, Kahlow B, Skare T, Tabushi F, Castro A. Uric Acid and Tissue Repair. ABCD Arquivos Brasileiros de Cirurgia Digestiva (São Paulo). 2015;28(4):290-292.

18. Pasare C, Medzhitov R. Toll-like receptors: linking innate and adaptive immunity. Microbes and Infection. 2004:6(15):1382-1387.

19. Poutahidis T, Kearney S, Levkovich T, Qi P, Varian B, LakritzJ etal. Microbial Symbionts Accelerate Wound Healing via the Neuropeptide Hormone Oxytocin. PLoS ONE. 2013;8(10):e78898.

20. Radek,K.and Gallo, R.(2010).Amplifying Healing:TheRoleofAntimicrobial Peptides in Wound Repair. Advances in Wound Care, 1, pp.223-229.

21. Salgado F, Artigiani-neto R, Lopes-filho G. Growth Factors and Cox2 in Wound Healing: an Experimental Study with Ehrlich Tumors. ABCD Arquivos Brasileiros deCirurgia Digestiva(SãoPaulo).2016;29(4):223-226.

22. Sato T, Yamamoto M, Shimosato T, Klinman D. Accelerated wound healing mediated by activation of Toll-like receptor 9 . Wound Repair and Regeneration. 2010:18(6):586-593.

23. Scotti E, Boué S, Sasso G, Zanetti F, Belcastro V, Poussin C et al. Exploring themicrobiomeinhealthand disease. Toxicology ResearchandApplication 2017;1:239784731774188

24. Tagliari E, Campos A, Costa-Casagrande T, Salvalaggio P. The Impact of the Use of Symbiotics in the Progression of Nonalcoholic Fatty Liver Disease in a Rat Model. ABCD Arquivos Brasileiros de Cirurgia Digestiva (São Paulo). 2017;30(3):211-215.
25. Vizzotto Junior A, Noronha L, Scheffel D, Campos A. Influência da cisplatina administrada no pré e no pós-operatório sobre a cicatrização de anastomoses colônicas em ratos. Jornal Brasileiro de Patologia e Medicina Laboratorial. 2003;39(2):143-149.

26. WagnerN,ZaparolliM, CruzM,SchieferdeckerM,CamposA. Postoperative Changes in Intestinal Microbiota and use of Probiotics in Roux-en-y Gastric Bypass and Sleeve Vertical Gastrectomy: an Integrative Review. ABCD Arquivos Brasileiros de Cirurgia Digestiva (São Paulo). 2018;31(4).

27. Wang J, Hori K, Ding J, Huang Y, Kwan P, Ladak A et al. Toll-like receptors expressed by dermal fibroblasts contribute to hypertrophic scarring. Journal of Cellular Physiology. 2011;226(5):1265-1273.

28. WILGUS T. Immune cells in the healing skin wound: Influential players at each stage of repair. Pharmacological Research. 2008;58(2):112-116.

29. World Gastroenterology Organization (WGO), Probiotics and prebiotics. 2017.Availablefrom:http://www.worldgastroenterology.org/guidelines/ global-guidelines/probiotics-and-prebiotics/probiotics-and-prebioticsenglish [Accessed 16th July 2019] 